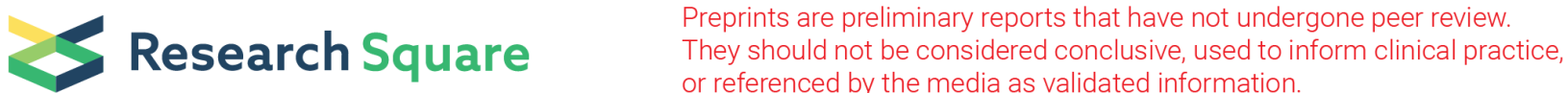

\section{Traditional Knowledge of Plant Dyeing, Sustainable Practices and Potential for Improved Techniques by Monpa in Tibet, China}

\section{Rong Yang}

Southwest Forestry University

Yu Zhang

Kunming Institute of Botany Chinese Academy of Sciences

Sailesh Ranjitkar

Kunming Institute of Botany Chinese Academy of Sciences

Mingxiang Li

Kunming Institute of Botany Chinese Academy of Sciences

Yongjie Guo

University of chinese academic of science

Xiuxiang Yan

Kunming Institute of Botany Chinese Academy of Sciences

Chuanfa Wang

Southwest Forestry University

John Richard Stepp

University of Florida

Lixin Yang ( $\square$ rattan@mail.kib.ac.cn )

Southwest Forestry University;Kunming Institute of Botany Chinese Academy of Sciences;Center for Biodiversity and Indigenous Knowledge https://orcid.org/0000-0002-1108-9632

\section{Research}

Keywords: Ethnobotany, Sustainability, Monpa people, Madder dyeing, Color properties

Posted Date: December 8th, 2020

DOI: https://doi.org/10.21203/rs.3.rs-116796/v1

License: (9) (7) This work is licensed under a Creative Commons Attribution 4.0 International License. Read Full License 


\section{Abstract}

Background

Natural dyes used since historic times for coloring food, leather, textile fibers, and paint body parts. The use of natural dyes has suffered drastically under the influence of modern technologies in the textile industry and socio-economic changes. Hence, ethnobotanical studies of indigenous dye plants and dyeing craft in local communities are urged to protect their potential ecological and economic value.

Methods

We conducted semi-structured surveys on dye plants and traditional craft in 11 Monpa villages of Mêdog County, South-east Tibet, China. The cultural significance of local dye plants was evaluated by an index of cultural importance (Cl). Field research was conducted to record the indigenous madder (the root of Rubia wallichiana Decne.) dyeing craft. An experiment was performed with aqueous extract and ethyl alcohol extract of residue remained after water extraction. These two dye solutions were respectively used to dye two fabrics with two biomordants and two metallic mordants by three mordanting methods. We evaluated color properties that were characterized by physicochemical evaluations using UV-visible spectroscopy and FTIR analysis. The dyed fabrics were evaluated by indicators of color strength and fastness including washing, rubbing, and perspiration.

Results

Altogether 15 species belong to 12 families were listed as dye plants, which were used in cloth and food dyeing. The Cl of $R$. wallichiana was highest. Monpa ethnic group used madder directly or with metallic mordants. It was found experimentally that biomordants and metallic mordants were comparable in improving the dyeing properties of indigenous madder. The dyeing properties of both extracts of madder were equal or ethyl alcohol extraction was marginally better.

Conclusions

Use of dye plants and indigenous knowledge of dyeing still present in the Monpa ethnic group. Our experiment revealed the feasibility of enhancing the dyeing property and reuse of the residue from madder dyeing. The improved dyeing and reuse of residue can improve the ecological and economic benefits of local meanwhile provide basic application research for the subsequent commercialization of plant dyes.

\section{Background}

Monpa ethnic groups live in Mêdog County in the south-eastern Tibet, at the edge of two "biodiversity hotspots" and culturally diverse of Himalayan and the Indo-Burma, where is called "third pole of the earth". It is one of sensitive ecological environments for global climate change. However, their traditional knowledge which supported this fragile ecosystem has nearly disappeared, while rare and endangered plant species are abundant. It is the obvious that this special region will not been carried by any environmental pollution such as synthetic dyes. Hence, the improvement of plant dyeing industry is not only meaningful to the environmental conservation but also it can contribute to the economic development.

There is no denying the global economic contribution of the textile industry, which has become one of the most important industries in the world. In recent decades, textile and clothing production has seen dynamic growth along with increased international trade. Many of the Asian countries are the world's leading textile exporters that support the rapid economic growth of these countries [1]. China is the largest manufacturer and exporter of textiles worldwide. The textile industry is also one of the traditional pillars in the economy of China [2].

Although economically very important, it is one of the largest sources of greenhouse gas emissions that require high-energy consumption and cause high levels of pollution. The textile industry uses large amounts of freshwater along its entire value chain, particularly during dyeing for dissolving dyes and chemicals [3]. Furthermore, use of synthetic dyes has a distinct environmental impact and discharging wastewater create major pollution issues [4]. Synthetic dyes can not only pollute the environment and damage ecosystems but can also be harmful to human health [6-7].

Thus, a concept of eco-efficiency has been introduced that brings economic and environmental viability together [5]. Natural dyes, as a biodegradable and recyclable resource, are gradually beginning to receive more attention [8], and widely planted industrial crops are primarily used as the source of natural pigments [9]. In recent years, the frequency of using natural dyes has been increased for sustainable and eco-friendly textile dyeing [10-11]. Natural dyes could be extracted from natural resources, especially plants [12-13]. There is a long history of natural dyeing throughout the world [14-15]. Plant dyes are now becoming popular in the dyeing of cotton [16], hemp [17], silk [18] and wool fabrics [19]. In addition, plant dyes are widely applied in cosmetics, foods, medicines, clothing [20-22].

Anthraquinone dyes from plant dye are relatively stable and lightfast. Madder (Rubia spp.), as an anthraquinone dye source, has been a popular source of red color shades along with orange, gray, purple, pink, and brown shades [23]. Rubia tinctorum L. and Rubia cordifolia L. have been extensively used for dyeing throughout history. The main extract from $R$. tinctorum is alizarin, while the main extract from $R$. cordifolia is purpurin [10]. To the best our knowledge, no research on dyeing applications to-date have explored Rubia wallichiana Decne., although it is an important dye-yielding plant still used.

Dyeing with plant extracts is challenging, as they possess some disadvantages such as less or even no adhesion towards the textile substrate, lower yield and color fastness, and higher cost, which have restricted their potential in industrial-scale application. Howeverm mordants can help create a bond between dye and fabric fiber making the color brighter and improve color fastness [24]. Therefore, compatibility of mordant with the coloring agent is important. A range of metallic mordants are available, but metallic mordants can produce heavy metal pollution [25]. In contrast, biomordants, obtained from minerals, chitosans, sol-gels, and plants [26], can provide eco-friendly industrial production. Utilization of biomordants are gradually becoming a trend in sustainable ecological 
dyeing [27-28]. Therefore, it is useful to further study biomordants used traditionally such as the fruit of Chaenomeles speciosa (Sweet) Nakai [29], gum rosin [30] might be able to improve the effect of Rubia wallichiana D. in dyeing craft.

To that end this study aims to document and assists to present traditional Monpa dyeing craft through improved techniques. The specific objectives were: (1) to expand Monpa knowledge on textile dyeing with madder through scientific approaches; (2) to analyze efficiency of recycled madder with biomordant dyeing agent; (3) to explore chemical bonding of the plant dye, biomordants and textiles.

\section{Methods}

\section{Study site}

Mêdog County is located in the lower reaches of the Yarlung Tsangpo River, which is in the southeast of Tibet with a total area of $31,395 \mathrm{~km}^{2}$. It has an excellent natural environment and rich biodiversity. In Mêdog County annual average temperature is between $16^{\circ} \mathrm{C}$ and $18{ }^{\circ} \mathrm{C}$, the lowest temperature is $2{ }^{\circ} \mathrm{C}$ in January, and the highest temperature is $33.8^{\circ} \mathrm{C}$ in July; while annual average rainfall is $2350 \mathrm{~mm}$, frost-free period is about 330 days, and the average humidity is more than $80 \%$ [31-32]. Beibeng Township is the main settlement area of Monpa people that accounts for $99.2 \%$ of the total population [33]. Mêdog County is the last county which had access to highways, this led to less outside interactions in the past and has helped to preserve the traditional culture of the Monpa people. 11 traditional villages were selected as the study sites in Mêdog County (Fig.1). The research was carried out in four Townships, including Beibeng Township, Dexing Township, Bangxin Township and Jiaresa Township.

\section{Field research}

We used snowball sampling to recruit a group of participants that include 25 women and 20 men. A semi-structured interviews were conducted during August 2018 for documenting traditional knowledge of Monpa ethnic groups on dye yielding plants. The age of informants ranged mainly from 18 to 85 years. The interview questions focused on seven questions: (1) When do you collect dye plant? (2) What is the local name of dye plant? (3) Where does dye plant grow in your community? (4) Which part of dye plant do you mainly use for dyeing? (5) What are your processes for indigenous dye plant dyeing? (6) Do you add anything else to the plant dyeing process? (7) Do you mainly use dye plant for dyeing food or fabric?

The information of these dye plants was made into an ethnobotanical catalog which included herbarium voucher code, Chinese name, scientific name, Monpa name, family name, life form, parts used, color, habitat and medicinal value (Table 1). All voucher specimens were identified and verified by local Monpa people, botanist and experts from Kunming Institute of Botany.

\section{Data analysis}

We evaluated the cultural significance of each dye plant following Tardío and Pardo-de-Santayana [34], that used following relation:

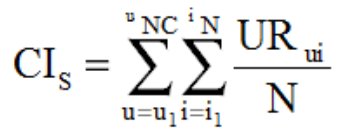

$\mathrm{N}$ represents the total number of informants; $\mathrm{NC}$ represents the sum number of applications, for the species of dye plant $\mathrm{S}$; UR $\mathrm{R}_{\mathrm{ui}}$ is a an utilization report (UR) for the species $\mathrm{S}$ referred by informant in application $\mathrm{u}$; Therefore, the $\mathrm{Cl}$ represents the total proportion of informants that referred each type of the use of a given species.

This index reveals the diversity of use of each plant species and the recognition degree of a use of certain plant species by informants. The high Cl value illustrates the plant has many applications and is known by most people.

\section{Materials}

Ethnobotancal surveys were conducted on dyed plants and related traditional knowledge from Monpa ethnic groups, as well the roots of $R$.wallichiana (madder) were collected in Autumn 2018 from De' ergong Village (29 $\left.13^{\prime} 43^{\prime \prime} \mathrm{N}, 9^{\circ} 08^{\prime} 11^{\prime \prime E}\right)$, Beibeng Township of Mêdog County, Lin Zhi City, South-east Tibet, China. Recycled madder is the residue madder root, which came from a filtered indigenous dye solution that was extracted in water without mordant. Two biomordants including the fruit of $C$. speciosa and gum rosin were collected from the local period market in Heqing County, Dali Bai Autonomous Prefecture of China. Metallic mordants including alum, stannous chloride and ethyl alcohol used were all in analytical reagent grade. Bleached cotton and hemp fabrics were provided by Esquel Enterprises Ltd.

\section{Laboratory experiments}

\section{Extraction of plant dye}


The roots of madder were water-washed to remove impurities and cut into segments. Then, $100 \mathrm{~g}$ of the madder roots was put into $2.5 \mathrm{~L}$ of distilled water and boiled for 30 minutes. After cooling, the solution was filtered, and the filtrated extract was diluted with water to $2.5 \mathrm{~L}$. This was the dye solution of madder. Subsequently, the residue roots of madder were extracted again by the mixture of $1.5 \mathrm{~L}$ ethyl alcohol and $1 \mathrm{~L}$ distilled water at $60^{\circ} \mathrm{C}$ for 30 minutes [35]. This was the dye solution of recycled madder.

\section{Dyeing}

$4 \%$ madder was used to dye cotton (weight $118.7 \mathrm{~g} \mathrm{~m}^{-2}$, plain weave) and hemp (weight $149.1 \mathrm{~g} \mathrm{~m}^{-2}$, plain weave) fabrics at $80^{\circ} \mathrm{C}$ for 30 minutes with a bath ratio of 30:1 with a laboratory method. After dyeing, the dyed samples were rinsed with tap water and dried at room temperature.

\section{Mordanting methods}

Pre, simultaneous and post mordanting methods were implemented at $80^{\circ} \mathrm{C}$ for 30 minutes at a liquor ratio of $30: 1$ by two metallic mordants ( $10 \%$ owf alum and stannous chloride) and two biomordants $\left(20 \mathrm{~g} \mathrm{~L}^{-1}\right.$ C. speciosa, $12 \mathrm{~g} \mathrm{~L}^{-1}$ gum rosin).

\section{Color measurements}

The color characters, including color difference $\left(\Delta E^{\star}\right)$, lightness $\left(L^{\star}\right)$, redness-greenness $\left(a^{\star}\right)$, and blueness-yellowness $\left(b^{\star}\right)$ of dyed samples were carried out by benchtop spectrophotometer (Shenzhen ThreeNH Technology Co., Ltd), in illuminant D65 and $10^{\circ}$ standard observer. The standard samples were undyed fabrics. $K / S$ was calculated by Kubelka-Munk equation:

$K / S=(1-R)^{2} / 2 R$

where $R$ is the reflectance of the dyed fabric, $K$ is the absorption coefficient, and $S$ is the scattering coefficient.

\section{Colorfastness tests}

The color fastness of dyed samples was tested with reference to Chinese Textiles Test Specification before and after mordanting. The color fastness to washing, perspiration and rubbing was measured according to the standard of GB/T3921-2008, GB/T3922-2013 and GB/T3920-2008 [36-38], relatively, which are based on ISO international standards. According to which, a numerical grading is assigned on a scale of $1-5$, where 1 is poor and 5 is excellent. Generally, level 3 is the basic standard, a grade of 4 and above is considered acceptable for commercial use.

\section{Phyotochemical analysis}

Borntrager reaction was a special chromogenic experiment, which was designed to detect hydroxyl anthraquinone components in plants and based on the characteristics of hydroxyl anthraquinone and its glycosides showing red or purplish-red in alkaline solution [39]. $100 \mathrm{mg}$ of aqueous extract was used to analyze, $2 \mathrm{ml}$ of diethyl ether, $1 \mathrm{ml}$ of $5 \%$ sodium hydroxide, and $5 \mathrm{ml}$ of $10 \%$ concentrated sulphuric acid were used for the analysis on compound present in the aqueous extract in this study.

\section{FTIR and UV-visible analysis}

UV-visible spectrophotometer analysis of madder extract was conducted by scanning from 190 to 600 nm wavelength using UV-5500PC spectrophotometer (Shanghai Metash Instruments Co., Ltd).

The FT-IR spectra of madder extract was confirmed by Fourier transform infrared spectrometer (Nicolet iS10, ThermoFisher Scientific), with 16 scans at 4 cm ${ }^{-1}$ resolution in the spectral range of $4000-400 \mathrm{~cm}^{-1}$. The method of $\mathrm{KBr}$ pellet was used for spectrum data.

\section{Results}

\section{Ethnobotanical study of the Monpa dye plants}

\section{The diversity of dye plants in Monpa communities}

Altogether 15 species belonging to 12 plant taxonomic families were recorded in the study area that were used as dye plants. The species record were mainly herbaceous (10), while the remaining were trees (3), shrubs (2). The plant parts used for extracting pigment included leaves (6), stems (5), roots (4), peels (3), fruits (2), barks (2) and flowers (1). A variety of colors were produced from dye plants, such as red, yellow, blue, black, green, purple and so on. Indigenous people used dye plants to dye cloth, food and also occasionally paint nails. These dye plants occurred in different environments and most of them also possess medicinal properties. 


\section{Evaluation of indigenous knowledge on dye plants}

The $\mathrm{Cl}$ value was used as a quantitative indicator to evaluate 15 species of dye plants. It sorted by the size of the indicators in Table 2 , Rubia wallichiana Decne. (2.11), Baphicacanthus cusia (Nees) Bremek. (2.04), Juglans regia L. (2.00), Curcuma longa L. (1.96), Zingiber officinale Rosc.(1.89), Rubia membranacea Diels. (1.80) revealed higher $\mathrm{Cl}$ values, and the $\mathrm{Cl}$ value of $R$.wallichiana was the highest. A high $\mathrm{Cl}$ value indicates that plants have many uses, and the respondents have a deep understanding of plant use. It also shows that plants have a high cultural importance to the Monpa. The use of R.wallichiana is of great significance in the region. Phytolacca acinosa Roxb. (0.84), Elaeocarpus decipiens Hemsl. (0.69) , Eurya acuminata DC. (0.44) have lower $\mathrm{Cl}$ values. This possibly illustrates that these dye plants have few other uses. Some respondents consider these plants important and highly useful.

\section{The traditional knowledge of madder dyeing}

The analysis and evaluation show that the index of cultural importance on R.wallichiana is highest, so we conducted further research on this species. According to the field investigation (Fig. 2), we found that indigenous madder dyeing was still in existence and Monpa people preserved madder dyed clothes as expression of Monpa cultural identity. The madder is known locally as 'Lae-nyi' in Monpa language and it is mainly growing in the edge of the forest margins or shrubs at an elevation of 1500-3080m. Monpa men used to collect the root of R.wallichiana each year during Autumn season. We found two methods of dyeing cloth in Monpa communities. The first method was direct dyeing method mainly used to dye locally. The second method was advanced one that use metallic salts to fix the color or obtain more color. R.wallichiana is treated to retain only the roots which are dried and cut off, this is the pretreatment of materials. Subsequently, the madder pigment is extracted in boiling water for 30 minutes. Cotton or hemp lines were shocked in boiling water in another vessel to remove impurities for 10 minutes. The dye liquid was filtered and heated. Dyeing process include shocking cotton or hemp line in hot extract for 30 minutes with repetitively stirring with a stick. The reason for this was to prevent pigment from being unevenly dyed the lines. Then the number of dyeing was depended on the depth of the desired color, and if the lines were repeatedly dyed it would show darker colors. Dyeing was followed by drying and after that decision was made whether to add metallic salts or not. The dyed lines was washed to remove the floating color, after these were air-dried. Consequently, the dyed lines were spun into fabrics which were made into clothes (Fig. 3).

\section{Color measurement evaluation}

\section{Comparison of madder with biomordants and metallic mordants}

The findings of our experiment revealed the color strength of madder dyed fabrics was higher when biomordants were used. The maximum $\mathrm{K} / \mathrm{S}$ value was obtained in the dyed cotton and hemp (Table 3) fabrics with gum rosin in the post mordanting, and the minimum K/S value was obtained with stannous chloride in simultaneous mordanting. The results indicated that the maximum K/S values were obtained with biomordants. The post mordanting method was optimum mordanting method for metallic mordants. For example, the K/S value was higher in the post mordanting for cotton dyed fabrics with alum. This also verified the scientific nature of using metallic mordants by post mordanting in indigenous madder dyeing. The diverse colorimetric data confirmed the variation in the hue of the fabrics brought by different mordants and by different mordanting methods.

It was observed that the $\mathrm{K} / \mathrm{S}$ value of madder dyed fabrics with biomordants was higher than that of the metallic mordants in same mordanting method. Our results indicated biomordant can yield better results in cotton and hemp dyeing. The findings of this work concur with findings of [40], who recommend biomordants as an alternative to metallic mordants based on their superior properties than metallic mordants. Also, research elsewhere [41] reported that dyeing temperature, dyeing time, dye solution concentration, dyeing method, and interaction with mordant are significant in improving dyeing.

\section{Comparison of recycled madder with biomordants and metallic mordants}

The K/S values of dyed fabrics under the method of indigenous madder dyeing were lower than the dyed fabrics with biomordants in same mordanting method. Dyed cotton and hemp (Table 4) fabrics showed the maximum K/S value with gum rosin in simultaneous mordanting, while the minimum K/S value obtained without mordant. It was observed that the two fabrics yielded the maximum K/S values with biomordants. The findings indicated that biomordants were effective with recycled madder and perform superior to metallic mordant in three mordanting methods.

\section{Comparative effects on color strength of dyed fabrics between madder and recycled madder}

Our results indicated that the biomordants could compete with metallic mordants and even exceed them for the improvement of dyeing the fabrics used in this study. The comparison of color strength and effectiveness of biomardants while dyeing with madder and recycled madder in three mordanting methods were carried out and plotted in Fig. 4.

In the case of cotton and hemp, the K/S values of recycled madder dyed samples with biomordants were higher than madder dyed samples in the same mordanting methods. For instance, the K/S values of recycled madder dyed samples with gum rosin were higher than madder dyed samples by gum rosin in the simultaneous mordanting method. Similarly, for hemp the K/S values of recycled madder dyed samples with $C$. speciosa were higher than madder dyed samples in the simultaneous methods. Our results indicated that the most obvious effect of improving color strength was recycled madder dyed fabrics with biomordants. 


\section{Colorfastness properties}

\section{The colorfastness of dyed fabrics with madder}

The color fastness of two fabrics dyed with madder was shown in Table 5. The color fastness of dyed samples with mordants was mostly higher than without mordant, except that the color fastness to perspiration and washing were slightly lower. The color fastness to rubbing in dyed samples with biomordants was 4-5 and 5 , and the staining to washing scored 4, 4-5, and 5 . The color fastness of dyed samples to perspiration was generally increased with biomordants to 4 , $4-5$, and 5 .

The results showed that the color change fastness under washing was comparatively higher with mordant than without mordant. In case of madder dyed cotton with biomordants, color fastness to washing was better (score 3 in post-mordanting using gum rosin) compared to results without mordants. And the results indicated that the color fastness to perspiration was improved and scored 5 with $C$. speciosa, while scored 4-5 with stannous chloride.

The colorfastness of dyed fabrics with recycled madder

The color fastness of two fabrics with recycled madder-dyed was shown in Table 6. The results indicated that the color fastness of recycled madder-dyed samples with mordants were strengthened, except the color change. The color fastness of recycled madder dyed samples with biomordants to rubbing was 4 5 and 5 . Similarly, the color staining in washing and perspiration showed value 4, 4-5 and 5 with biomordant.

The results indicated the color change in washing was improved in samples with biomordants. The color change in washing was better (score 3 ) with biomordants in the post-mordanting method comparing to without mordant (score 1-2).

Our results clearly indicated that the color change in washing was improved and scored 3 with $C$. speciosa, while it was 2 with alum. The experiment results clearly indicated that biomordants were able to enhance the color fastness in both fabrics dyed with recycled madder.

\section{Phyotochemical analysis of extracts}

The chromogenic reaction was related to the phenolic hydroxyl and carbonyl groups forming the conjugate system. Both the aqueous extract and the ethyl alcohol extract from the root of $R$. wallichiana were tested their Borntrager reaction. The results suggested that these two extracts showed similar color changes. The ether layer of both extracts was brown, but when $\mathrm{NaOH}$ solution was added, the ether layer turned colorless and the water layer turned red. Their color change indicates two extracts of $R$. wallichiana contained hydroxyl anthraquinone components.

\section{FTIR and UV-visible analysis}

The UV-visible absorption spectra of madder aqueous extraction and ethyl alcohol extraction were showed in Fig. 5. Both extractions showed similar UVvisible absorption. UV-visible absorption of aqueous extraction showed the peaks ( $\lambda$ max) at 195.50 (0.677), 241.50 (0.204), 259.00 (0.189), and 271.50 $(0.195) \mathrm{nm}$. The absorption of $241.5 \mathrm{~nm}$ and $259 \mathrm{~nm}$ could be speculated as the signal of benzene structure. The absorption signal of $271.5 \mathrm{~nm}$ was the characteristic signal of quinones. These absorption signals were similar to UV absorption of anthraquinone components previous reported [42].

The results for the FTIR analysis carried out to understand the functional groups in the madder aqueous and ethyl alcohol extract were shown in Fig. 6. Two extracts showed similar IR characteristic signals. The IR spectra indicated higher absorption in ethyl alcohol extract at wavelengths $3422,2927,1616,1600$, $1384,1078,1040 \mathrm{~cm}^{-1}$. The spectrum showed a broad peak of phenolic $-\mathrm{OH}$ group at $3422 \mathrm{~cm}-1$. The peak at $1626 \mathrm{~cm}^{-1}$ indicated presence of $\mathrm{C}=0$ with a-OH, and the peaks at $2973 \mathrm{~cm}^{-1}$ and $1384 \mathrm{~cm}^{-1}$ indicated the presence of $\mathrm{C}-\mathrm{H}$ stretching in alkanes. The peak at $1600 \mathrm{~cm}^{-1}$ corresponds to the $\mathrm{C}=\mathrm{C}$ stretching of the benzene ring system [43]. The findings of the infrared characteristics suggested that the extract possibly contained anthraquinone components.

\section{Discussion}

\section{The curren $\mathrm{t}$ status of madder dyeing in Monpa communities}

The collection of madder is important in Mêdog County, because the Monpa and Tibetan robes are dyed with madder. There are 45 key informants in this study in which the number of females is more than that of males, and the number of elder is greater than young people. We found a division of labor with regards to dyeing: the collection and extraction of dye plants are done by men, while the dyeing, weaving clothes and designing patterns are done by women. In our study area, after men went out to work in the daytime, women would gather together in groups and chat while sewing clothes, allowing for multi-tasking. Monpa costumes were mostly wore by old women, especially in festivals. With the influence of outside culture, non-traditioanl clothes are usually worn by younger people. With the development of the economy, more and more local young people yearn for seeking new opportunities in cities. Most of them believe that indigenous madder dyeing will not bring much profit because the production process is complicated and arduous and they don't want to be involved in indigenous madder dyeing. Monpa is not a written language and the traditional knowledge related to madder dyeing can only be inherited by oral tradition. Regarding these issues, the following suggestions are made: (1) the existing traditional knowledge about plant dyeing needs to be recorded, collated and studied urgently by ethnobotanical methods. (2) it is important to establish a community market for the production, sale of dye plants and related products, which could stimulate local people to engage traditional plant dyeing. (3) local governments should provide support for plant dyeing industry and the research of plant dyeing. 


\section{Evaluation of possible mechanism}

The plants in the family of Rubiaceae have been used as plant dyes since prehistoric times. The main colorants extracted from its roots are anthraquinone derivatives (Fig. 7), which are purpurin (1), xanthopurpurin (2), 1-hydroxy-2-methylanthraquinone (3), rubiadin (4), nordamnacanthal (5), lucidin (6), and munjistin methyl ester (7) [44-46]. The hydroxy group in the 4-site of anthraquinone derivatives can form a six-membered ring through a hydrogen bond with carbonly group in the 10-site of the anthraquinone molecule, which was chelated with metal ions [47-48]. However, if $R_{3}$ is a hydroxide radical group, one of the anthraquinone derivatives, the structure of the ortho-dihydroxyl group may enhance the chelation observably [45]. Furthermore, van der Waals forces and intermolecular hydrogen bonds are formed with the hydroxy group in the 4-site and the carbonyl group in the 10-site of anthraquinone derivatives, resulting in that the molecule of plant dyes combine with biomordants.

The possible mechanism between $C$. speciosa, cotton/hemp and the pigment of $R$. wallichiana be illustrated in Fig. 8. C. speciose could help anthraquinone derivatives to form phenol through electron migration because of its acidity. The phenolic form was more likely to react with the cellulose fiber, thus increasing the color fastness of the dyed cellulose fibers. In addition, the major fixing mechanism of gum rosin in color properties attributes mainly to its physical properties of a film on the surface of fiber formed by cross-linking, and secondarily to its chemical property of the hydrogen bonding intermolecular forces [30]. Meanwhile, the main component of gum rosin is resin acid $\left(\mathrm{C}_{19} \mathrm{H}_{29} \mathrm{COOH}\right)$ [49], and its binding sites include carboxyl group and double bond, which was able to form chemical bond with anthraquinone derivatives and fibers. As a result, the possible mechanism that biomordants, which can be applied in the traditional dye standard and improve color properties.

\section{Cost estimation and future prospects}

Waste water from the production of synthetic dyes is harmful to the environment and human health, hence, it must be usually treated before discharging into rivers or public water bodies, according to the environmental laws in China and elsewhere [17]. On the contrary, sustainable plant dyes can be economically more cost effective and have a huge potential to be mainstreamed into the textile industry.

The comparative cost of synthetic and plant dyeing shown in Table 7. Employing all data, the cost of recycled madder dyeing was lower than madder dyeing by $7.4 \%$. Moreover, the costs of madder dyeing and recycled madder dyeing were greater than synthetic dyeing by $34.7 \%$ and $24.8 \%$ respectively. Currently, due to market demand, plant dye is becoming more commonly used for production by some high-end textile enterprises [50].

The estimation of this study showed that $1.2 \mathrm{~kg}$ of madder or recycled madder with biomordants were used for $1 \mathrm{~kg}$ dyeing fabrics through aqueous (indigenous Monpa approaches) or ethyl alcohol (improved by this study) extraction. This improved dye craft could dye more fabrics than indigenous Monpa dyeing, and using waste roots could reduce the cost of materials for madder dyeing. As far as human health and environmental concerned, plant dyeing and recycled plant dyeing are more preferable than synthetic dyeing, this illustrated that it has a great prospect in the textile industry. Although the costs of madder and recycled madder dyeing are slightly higher than synthetic dyeing, madder and recycled madder dyeing are more ecologic and safer in terms of the industry production, customer and environment.

\section{Conclusion}

Based on ethnobotanical research of indigenous madder dyeing in Monpa ethnic groups, we found that 15 species from 12 plant families were utilized for dyeing by ethnobotany cataloging table. Simultaneously, madder was identified as the most significant under the evaluation of $\mathrm{Cl}$ value. We propose a process of the utilization of dye residue that is generally abandon in the indigenous madder dyeing process, and the transformation of residue into a secondary colorant for the textile industry. The innovative dyeing craft with biomordants for cotton and hemp fabrics with madder was established and it exhibits good color properties, ecological and economic benefits. In this approach, it as a more sustainable alternative to other dyes, while madder and recycled madder dyeing with biomordants are better for the environment. Dyed fabrics presented various color phenomenons depending on mordants, mordanting methods, and the types of fabrics. Biomordants can be used to improve or reduce color strength and enhance or weaken the color fastness depending on their own attributes and types. It is necessary that biomordants should be further studied to release the potential of wider color gamuts with satisfactory fastness, to replace the metallic mordants. As future prospects, it will be meaningful to explore the possibility of dyeing other types of fibers, and especially distinguish the types of anthraquinone primary for the coloring, simultaneous the types of chemical bonds between the colored substances and the natural fibers. This can be further developed to give better results by refining the dye extracted from the madder or recycled madder as well as the biomordants used. The dyed fabrics with biomordants have characters, including skin-friendliness, health and good fastness properties.

Our results revealed that the residue from indigenous madder dyeing was a potential source of plant dye for dyeing cotton and hemp fabrics. It can be effectively applied for ecological dyeing textiles with biomordants. Improving the traditional dyeing craft could lead to the sustainable use of plant dye and the development of the ecological textile industry. Ethnobotanical approaches can discover important knowledge that can lead to new approaches for industry production. This study provides useful information for possible commercialization of traditional knowledge of Monpa ethnic groups of Himalayas on local plant use as a colorant. The findings bridge a link between traditional knowledge system and textile industry development that could adopt a industry production using eco-friendly natural anthraquinone containing dye and biomordants.

\section{Declarations}

\section{Acknowledgments}


We are very thankful to the local people in De'ergong Village, Beibeng Township of Mêdog County, Lin Zhi City, South-east Tibet, China, who have provided valuable

information related to the useful plant resources. Extremely gratitude is expressed to the families of Dawa Quzhen for their kind hospitality and genuine assistance.

\section{Funding}

Fabrics used in the experimental were all sponsored by Esquel Enterprises Ltd. This study was supported by National Nature Science Foundation of China (No. 31670340 and 31970357), Strategic Priority Research Program of Chinese Academy of Sciences (No. XDA20050204, XDA19050301, and XDA19050303), and the Second Monpa Plateau Scientific Expedition and Research Program (No. 2019QZKK0502).

\section{Availability of data and materials}

All data generated or analysed during this study are included in this published article and its supplementary information files.

\section{Authors' contributions}

RY and CFW conceived and designed this research. YZ, MXL and YjG conducted the field surveys and collected the data. XXY provided conceptualization and methodology. RY, SR and JRS performed literature review, analyzed the data, and wrote the manuscript. Lixin Yang funded this study. All authors read and approved the final manuscript.

\section{Ethics approval and consent to participate}

The authors asked for permission from the local authorities and the people interviewed to carry out the study.

\section{Consent for publication}

The people interviewed were informed about the study's objectives and the eventual publication of the information gathered, and they were assured that the informants' identities would remain undisclosed. Moreover, the owners have agreed to the portraits we used.

\section{Competing interests}

The authors declare that they have no competing interests.

\section{Author details}

${ }^{1}$ Southwest Forestry University, Kunming 650224, Yunnan, China. ${ }^{2}$ Key Laboratory of Economic Plants and Biotechnology, Kunming Institute of Botany, Chinese Academy of Sciences, Kunming 650201, Yunnan, China. ${ }^{3} \mathrm{NGene}$, Solutions of Natural Innovation, Kathmandu 44614, Nepal. ${ }^{4}$ Mid-Western University, Faculty of Humanities and Social Science, Lalitpur 44700, Nepal. ${ }^{5}$ Center for Biodiversity and Indigenous Knowledge, Kunming 650034, Yunnan, China. ${ }^{6}$ State Key Laboratory of Phytochemistry and Plant Resources in West China, Kunming Institute of Botany, Chinese Academy of Sciences, Kunming 650201 , Yunnan, China. ${ }^{7}$ Ethnobiology Lab, Department of Anthropology, University of Florida, Gainesville, FL 32611-7305, USA. ${ }^{8}$ Germplasm Bank of Wild Species of China, Kunming Institute of Botany, Chinese Academy of Sciences, Kunming 650201, Yunnan, China. ${ }^{9}$ University of Chinese Academy of Sciences, Beijing CN100049, China.

\section{References}

1. Corovic E, Jovanovic P, Ristic L. Current Trends on the World Textile Market and the Competitiveness of the Serbian Textile Industry. Fibres. Text. East. Eur. 2013; 101: 8-12.

2. Wang XP, Chen X, Cheng YM, et al. Factorial Decomposition of the Energy Footprint of the Shaoxing Textile Industry. Energies. 2020;13(7):1683. https://doi.org/10.3390/en13071683.

3. Haji A, Naebe M. Cleaner dyeing of textiles using plasma treatment and natural dyes: A review. J. Clean. Prod. 2020. 121866. https://doi.org/10.1016/j.jclepro.121866.

4. Xi L, Li ZY, Liu YA. Titanium dioxide coated carbon foam as microreactor for improved sunlight driven treatment of cotton dyeing wastewater. J. Clean. Prod. 2020;246:118949. https://doi.org/10.1016/j.jclepro.2019.118949. 
5. Angelis-Dimakis A, Alexandratou A, Balzarini A. Value chain upgrading in a textile dyeing industry. J. Clean. Prod. 2016;265:121866. https://doi.org/10.1016/j.jclepro.2020.121866.

6. Manian AP, Paul R, Bechtold T. Metal mordanting in dyeing with natural colorants. Color. Technol. 2016;132(2):107-113. https://doi.org/10.1111/cote.12199.

7. Fras-Zemljič L, Kokol V, Čakara D. Antimicrobial and antioxidant properties of chitosan-based viscose fibres enzymatically functionalized with flavonoids. Textil. Res. J. 2011;81:1532-1542. https://doi.org/10.1177/0040517511404600.

8. Shams NA. Reusing wastewater of madder natural dye for wool dyeing. J. Clean. Prod. 2011;19:775-781. https://doi.org/10.1016/j.jclepro.2010.12.018.

9. Cerempei A, Mureşan El, Cimpoeşu N, Carp-Cărare C, Rimbu C. Dyeing and antibacterial properties of aqueous extracts from quince (Cydonia oblonga) leaves. Ind. Crops Prod. 2016;94:216-225. https://doi.org/10.1016/j.indcrop.2016.08.018.

10. Feiz M, Norouzi H. Dyeing studies of wool fibers with madder (Rubia tinctorum) and effect of different mordants and mordanting procedures on color characteristics of dyed samples. Fibers. Polym. 2014;15:2504-2514. https://doi.org/10.1007/s12221-014-2504-x.

11. Khan Ml, Ahmad A, Khan SA, et al. Assessment of antimicrobial activity of Catechu and its dyed substrate. J. Clean. Prod. 2011;19:1385-1394. https://doi.org/10.1016/j.jclepro.2011.03.013.

12. Patricia Muniz dos Santos S, Ticiane Rossi F, Rayana Santiago de Q, et al. Natural dye from Croton urucurana Baill. bark: Extraction, physicochemical characterization, textile dyeing and color fastness properties. Dyes. Pigments. 2020;173:107953. https://doi.org/10.1016/j.dyepig.2019.107953.

13. Meliha OB, Ezgi A. Ecological dyeing with some plant pulps on woolen yarn and cationized cotton fabric. J. Clean. Prod. 2012;32:1-9. https://doi.org/10.1016/j.jclepro.2012.03.010.

14. Li F, Zhuo J, Liu B, et al.. Ethnobotanical study on wild plants used by Lhoba people in Milin County, Tibet. J. Ethnobiol. Ethnomed. 2015;11:23. https://doi.org/10.1186/s13002-015-0009-3.

15. Fan YX, Zhao YQ, Liu AZ, Hamilton A, Wang CF, Li LQ, Yang YK, Yang LX. Indigenous knowledge of dye-yielding plants among Bai communities in Dali, Northwest Yunnan, China. J. Ethnobiol. Ethnomed. 2018;14:74. https://doi.org/10.1186/s13002-018-0274-z.

16. Vankar PS, Shukla D. Natural dyeing with anthocyanins from Hibiscus rosa sinensis flowers. J. Appl. Polym. Sci. 2011;122:3361-3368. https://doi.org/10.1002/app.34415.

17. 17. Grifoni D, Bacci L, Di-Lonardo S, et al. UV protective properties of cotton and flax fabrics dyed with multifunctional plant extracts. Dyes. Pigments. 2014;105:89-96. https://doi.org/10.1016/j.dyepig.2014.01.027.

18. Lee YH. Dyeing, fastness, and deodorizing properties of cotton, silk, and wool fabrics dyed with coffee sludge (Coffea arabica L.) extract. J. Appl. Polym. Sci. 2007;103(1):251-257. https://doi.org/10.1002/app.25221.

19. Mongkholrattanasit R, Kryštůfek J, Wiener J. Dyeing and fastness properties of natural dyes extracted from eucalyptus leaves using padding techniques. Fibers. Polym. 2010;11:346-350. https://doi.org/10.1007/s12221-010-0346-8.

20. Guesmi A, Ben-Hamadi N, Ladhari N, Sakli F. Dyeing properties and color fastness of wool dyed with indicaxanthin natural dye. Ind. Crop. Prod. 2012;37:493-499. https://doi.org/10.1016/j.indcrop.2011.07.026.

21. Velho SRK, Brum LFW, Petter CO, Dos-Santos JHZ, Simunic S, Kappa WH. Development of structured natural dyes for use into plastics. Dyes. Pigments. 2017;136:248-254. https://doi.org/10.1016/j.dyepig.2016.08.021.

22. Mohammad S, Shahid-ul-Islam, Faqeer M. Recent advancements in natural dye applications: a review. J. Clean. Prod. 2013;53:310-331. http://dx.doi.org/10.1016/j.jclepro.2013.03.031.

23. Mehrparvar L, Safapour S, Sadeghi-Kiakhani M, et al. A cleaner and eco-benign process for wool dyeing with madder, Rubia tinctorum L. root natural dye. Int. J. Environ. Sci. And. Technol. 2016;13:2569-2578. https://doi.org/10.1007/s13762-016-1060-x.

24. Azfarniam L, Norouzi M. Multifunctional polyester fabric using a multicomponent treatment. Fibers. Polym. 2016;17:298-304. https://doi.org/10.1007/s12221-016-5579-8.

25. Mansour HF, Heffernan S. Environmental aspects on dyeing silk fabric with sticta coronata lichen using ultrasonic energy and mild mordants. Clean. Technol. Environ. 2011;13:207-213. https://doi.org/10.1007/s10098-010-0296-2.

26. Cecilia RC, Askwar H, Stephen SN, et al. Suitability of selected vegetable tannins traditionally used in leather making in Tanzania. J. Clean. Prod. 2020;251:1-11. https://doi.org/10.1016/j.jclepro.2019.119687.

27. Gashti MP, Katozian B, Shaver M, et al. Clay nanoadsorbent as an environmentally friendly substitute for mordants in the natural dyeing of carpet piles. Color. Technol. 2014;130:54-61. https://doi.org/10.1111/cote.12065.

28. Santos CD, Brum LFW, Vasconcelos RDF, et al. Color and fastness of natural dyes encapsulated by a sol-gel process for dyeing natural and synthetic fibers. J. Sol-Gel. Sci. Technol. 2018;86:1-14. https://doi.org/10.1007/s10971-018-4631-0.

29. Chai ZZ, Wang YY, Wang YH. Investigation of Dai traditional dye plants in xishuangbanna. Guihaia. 2017;37:56-63.

30. Li XN, Cui YZ, Shi HB, et al. Application of rosin powder in cotton dyed with plant dyes. Journal of Dalian Polytechnic University. 2014;33:355-358.

31. Wang L. Investigation of Mêdog Village. Beijing: China Economic Publishing House; 2011.

32. Yang N, Zhou X. Plants of the Mê Bejing: China Forestry Publishing House; 2015.

33. Shan L, Yu Z, Yong JG, Li XY and Yu HW. Monpa, memory, and change: an ethnobotanical study of plant use in Mêdog County, South-east Tibet, China. J Ethnobiol Ethnomed. 2020; 5(16): 1-26. https://doi.org/10.1186/s13002-020-0355-7.

34. Tardío J, Pardo-de-Santayana M. Cultural importance indices: a comparative analysis based on the useful wild plants of southern Cantabria (northern Spain). Econ Bot. 2008; 62(1):24-39. https://doi.org/10.1007/s12231-007-9004-5.

Page 9/19 
35. Wei L, Hou XL, Zhou QC, et al. The extraction of madder dye and its dyeing properties on wool fabric. Wool Text. J. 2006;12:5-8. https://doi: 10. 1933/j. mfkj. 2006. 12. 001.

36. National Standard of the People's Republic of China, GB/T 3920-2008, Textiles-tests for color fastness-color fastness to Rubbing. China Standard Press, Beijing, P. R. China. 2008.

37. National Standard of the People's Republic of China, GB/T 3921-2008, Textiles-tests for color fastness-color fastness to Washing with Soap or Soap and Soda. China Standard Press, Beijing, P. R. China. 2008.

38. National Standard of the People's Republic of China, GB/T 3922-2013, Textiles-tests for color fastness-color fastness to Perspiration. China Standard Press, Beijing, P. R. China. 2013.

39. Xiao C, Hong LI. Determination of Total Anthraquinones in Health Foods by Direct Ultraviolet Spectrophotometry. Chinese Journal of Food Hygiene. 2007;19:47-48.

40. Ismal ÖE, Yıldııı L, Özdogan E. Valorisation of almond shell waste in ultrasonic biomordanted dyeing: alternatives to metallic mordants. J. Text. Inst. 2015;106:343-353, https://doi.org/10.1080/00405000.2014.949503.

41. Barani H, Maleki H. Plasma and Ultrasonic Process in Dyeing of Wool Fibers with Madder in Presence of Lecithin, J. Disper. Sci. Technol. 2011;32:11911199. https://doi.org/10.1080/01932691.2010.505525.

42. Isao K, Yoshihiro M. Cytotoxic anthraquinones from Rheum pulmatum. Phytochemistry. 1992;31:1063-1065.

43. Demirezer L, Kuruüzüm-Uz A, Bergere I. The structures of antioxidant and cytotoxic agents from natural source: anthraquinones and tannins from roots of Rumex patientia. Phytochemistry. 2001;58:1213-1217.https://doi.org/10.1016/S0031-9422(01)00337-5.

44. Drivas I, Blackburn RS, Rayner CM. Natural anthraquinonoid colorants as platform chemicals in the synthesis of sustainable disperse dyes for polyesters. Dyes. Pigments. 2011;88:7-17. https://doi.org/10.1016/j.dyepig.2010.04.009.

45. Vankar PS, Shanker R, Mahanta D, Tiwari SC. Ecofriendly sonicator dyeing of cotton with Rubia cordifolia Linn. using biomordant. Dyes. Pigments. 2008;76:207-212. https://doi.org/10.1016/j.dyepig.2006.08.023.

46. Xu K, Wang PL, Wang L, Liu CM, Xu SX, Cheng YT, Wang YH, Li Q, Lei HM. Quinone Derivatives from the Genus Rubia and Their Bioactivities. Chem. Biodivers. 2014;11:341-363. https://doi.org/10.1002/cbdv.201200173.

47. Gupta D, Kumari S, Gulrajani M. Dyeing studies with hydroxyanthraquinones extracted from Indian madder. Part 1: Dyeing of nylon with purpurin. Color. Technol. 2001;117:328-332. https://doi.org/10.1111/j.1478-4408.2001.tb00084.x.

48. Gupta D, Kumari S. Gulrajani M. Dyeing studies with hydroxyanthraquinones extracted from Indian madder. Part 2: Dyeing of nylon and polyester with nordamncanthal. Color. Technol. 2001;117:333-336. https://doi.org/10.1111/j.1478-4408.2001.tb00085.x.

49. Wang HW, Wang HH, Zhou GY, Wu GY, Seri Y. Application of rosin in polymer synthesis. Polymer Bulletin. 2011;1:51-58.

50. Komboonchoo S, Bechtold T. Natural dyeing of wool and hair with indigo carmine (C.I. Natural Blue 2), a renewable resource based blue dye. J. Clean. Prod. 2009;17:1487-1493. https://doi.org/10.1016/j.jclepro.2009.05.007.

\section{Tables}

\section{Table 1 Dye plants used by Monpa communities in Mêdog County.}




\begin{tabular}{|c|c|c|c|c|c|c|c|c|c|}
\hline $\begin{array}{l}\text { Herbarium } \\
\text { voucher } \\
\text { code }\end{array}$ & Chinese name & $\begin{array}{l}\text { Monpa } \\
\text { name }\end{array}$ & Scientific name & Family name & $\begin{array}{l}\text { Parts } \\
\text { used }\end{array}$ & $\begin{array}{l}\text { Life } \\
\text { from }\end{array}$ & Habitat & Color & Dye uses \\
\hline DX08 & Jianghuang & Jiong & $\begin{array}{l}\text { Curcuma longa } \\
\text { L. }\end{array}$ & Zingiberaceae & $\begin{array}{l}\text { Leaves, } \\
\text { root }\end{array}$ & Herb & $\begin{array}{l}\text { Herb in } \\
\text { plains, } \\
\text { mountain } \\
\text { meadows } \\
\text { and bushes }\end{array}$ & $\begin{array}{l}\text { Yellow, } \\
\text { golden } \\
\text { yellow, } \\
\text { orange }\end{array}$ & Cloth, food \\
\hline BB08 & $\begin{array}{l}\text { Guangjingqiancao } \\
\text { प्राप }\end{array}$ & Lae-nyi & $\begin{array}{l}\text { Rubia } \\
\text { wallichiana } \\
\text { Decne. }\end{array}$ & Rubiaceae & $\begin{array}{l}\text { Stem, } \\
\text { leaves, } \\
\text { root }\end{array}$ & Herb & $\begin{array}{l}\text { Herb under } \\
\text { forest or } \\
\text { thicket }\end{array}$ & Red & Cloth \\
\hline BG03 & $\begin{array}{l}\text { Hetao } \\
\text { प्र }\end{array}$ & $\begin{array}{l}\text { Da ga } \\
\text { xin }\end{array}$ & Juglans regia L. & Juglandaceae & Peel & Tree & $\begin{array}{l}\text { Tree in } \\
\text { hillsides, } \\
\text { valleys, } \\
\text { rivers and } \\
\text { forests }\end{array}$ & Brown & Cloth \\
\hline BB06 & $\begin{array}{l}\text { Banlan } \\
\text { 만 }\end{array}$ & $\begin{array}{l}\text { Yang } \\
\text { xian ba }\end{array}$ & $\begin{array}{l}\text { Baphicacanthus } \\
\text { cusia (Nees) } \\
\text { Bremek. }\end{array}$ & Acanthaceae & $\begin{array}{l}\text { Stem, } \\
\text { leaves }\end{array}$ & Herb & $\begin{array}{l}\text { Herb under } \\
\text { the trees, by } \\
\text { the stream }\end{array}$ & $\begin{array}{l}\text { Blue, } \\
\text { black }\end{array}$ & Cloth \\
\hline BB18 & Yujin & Dgrong & $\begin{array}{l}\text { Curcuma } \\
\text { aromatica } \\
\text { Salisb. }\end{array}$ & Zingiberaceae & $\begin{array}{l}\text { Root, } \\
\text { stem }\end{array}$ & Herb & $\begin{array}{l}\text { Herb under } \\
\text { the forest }\end{array}$ & Yellow & Cloth \\
\hline JR06 & $\begin{array}{l}\text { Jiang } \\
\square\end{array}$ & Sa-ga & $\begin{array}{l}\text { Zingiber } \\
\text { officinale Rosc. }\end{array}$ & Zingiberaceae & $\begin{array}{l}\text { Root, } \\
\text { stem }\end{array}$ & Herb & $\begin{array}{l}\text { Herb in } \\
\text { thickets, } \\
\text { hillside } \\
\text { forests }\end{array}$ & Yellow & Cloth, food \\
\hline BB16 & $\begin{array}{l}\text { Ruichifengxianhua } \\
\text { प्यास्टा }\end{array}$ & $\begin{array}{l}\text { Zhang } \\
\text { zeng } \\
\text { mu n }\end{array}$ & $\begin{array}{l}\text { Impatiens } \\
\text { arguta Hook. }\end{array}$ & Balsaminaceae & Flower & Herb & $\begin{array}{l}\text { Herb under } \\
\text { the forest, in } \\
\text { wet places, } \\
\text { and near the } \\
\text { ditch }\end{array}$ & Red & Cloth, nails \\
\hline DX02 & Sang & $\begin{array}{l}\text { Sen lin } \\
\text { xin }\end{array}$ & $\begin{array}{l}\text { Morus alba } \\
\text { Linnaeus. }\end{array}$ & Moraceae & Fruit & Shrub & $\begin{array}{l}\text { Tree in the } \\
\text { forest }\end{array}$ & Red & Cloth \\
\hline BG07 & $\begin{array}{l}\text { Banli } \\
\text { प्र }\end{array}$ & $\begin{array}{l}\text { Cai xin } \\
\text { se }\end{array}$ & $\begin{array}{l}\text { Castanea } \\
\text { mollissima Bl. }\end{array}$ & Fagaceae & $\begin{array}{l}\text { Peel, } \\
\text { leaves }\end{array}$ & Herb & $\begin{array}{l}\text { Tree in the } \\
\text { low hills } \\
\text { gentle slope } \\
\text { and river } \\
\text { beach area }\end{array}$ & $\begin{array}{l}\text { Yellow, } \\
\text { brown, } \\
\text { black }\end{array}$ & Cloth, food \\
\hline JR13 & Shanglu & $\begin{array}{l}\text { Mini } \\
\text { gan bu } \\
\text { ong }\end{array}$ & $\begin{array}{l}\text { Phytolacca } \\
\text { acinosa Roxb }\end{array}$ & Phytolaccaceae & Fruit & Herb & $\begin{array}{l}\text { Herb by the } \\
\text { side of the } \\
\text { road and } \\
\text { behind the } \\
\text { house }\end{array}$ & Purple,red & Cloth \\
\hline BG12 & $\begin{array}{l}\text { Hezi } \\
\text { प्र }\end{array}$ & $\begin{array}{l}\text { Ga xia } \\
\text { tong } \\
\text { xin }\end{array}$ & $\begin{array}{l}\text { Terminalia } \\
\text { chebula Retz. }\end{array}$ & Combretaceae & $\begin{array}{l}\text { Peel, } \\
\text { bark }\end{array}$ & Tree & $\begin{array}{l}\text { Tree in the } \\
\text { forest }\end{array}$ & $\begin{array}{l}\text { Yellow, } \\
\text { brown }\end{array}$ & Cloth \\
\hline DX09 & $\begin{array}{l}\text { Weijianyeling } \\
\text { प्सा }\end{array}$ & $\begin{array}{l}\text { Zem- } \\
\text { shing }\end{array}$ & $\begin{array}{l}\text { Eurya } \\
\text { acuminata DC. }\end{array}$ & Pentaphylacaceae & Leaves & Shrub & $\begin{array}{l}\text { Shrub on a } \\
\text { hillside in a } \\
\text { forest or } \\
\text { thicket. }\end{array}$ & $\begin{array}{l}\text { Yellow, } \\
\text { green }\end{array}$ & Cloth \\
\hline JR15 & $\begin{array}{l}\text { Jinxiancao } \\
\text { प्रा }\end{array}$ & Lae-nyi & $\begin{array}{l}\text { Rubia } \\
\text { membranacea } \\
\text { Diels. }\end{array}$ & Rubiaceae & Stems & Herb & $\begin{array}{l}\text { Herb in } \\
\text { forests, } \\
\text { forest } \\
\text { margins, } \\
\text { thickets, or } \\
\text { grasslands }\end{array}$ & $\begin{array}{l}\text { Orange, } \\
\text { red }\end{array}$ & Cloth \\
\hline BG10 & $\begin{array}{l}\text { Zisu } \\
\text { प्र }\end{array}$ & Lang & $\begin{array}{l}\text { Perilla } \\
\text { frutescens (L.) } \\
\text { Britt. }\end{array}$ & Labiatae & Leaves & Herb & $\begin{array}{l}\text { Herb under } \\
\text { the } \\
\text { hardwood } \\
\text { forest on the }\end{array}$ & $\begin{array}{l}\text { Yellow } \\
\text { green, } \\
\text { green, } \\
\text { Purple } \\
\text { red }\end{array}$ & Cloth, food \\
\hline
\end{tabular}




\begin{tabular}{|c|c|c|c|c|c|c|c|c|c|}
\hline & & & & & & & $\begin{array}{l}\text { hillside, or } \\
\text { homegarde }\end{array}$ & & \\
\hline DX05 & Duying & A ru & $\begin{array}{l}\text { Elaeocarpus } \\
\text { decipiens } \\
\text { Hemsl. }\end{array}$ & Elaeocarpaceae & Bark & Tree & $\begin{array}{l}\text { Tree in } \\
\text { mountain } \\
\text { and } \\
\text { rainforest }\end{array}$ & Brown & Cloth \\
\hline
\end{tabular}

Table 2 Cultural importance index of dye plants used by Monpa people.

\begin{tabular}{|lllll|}
\hline Scientific name & \multicolumn{3}{l}{ The type of use } & $\mathrm{Cl}$ \\
\cline { 2 - 5 } & Dye & Food & Medicine & \\
\hline Rubia wallichiana Decne. & 42 & 13 & 40 & 2.11 \\
\hline Baphicacanthus cusia (Nees) Bremek. & 39 & 14 & 39 & 2.04 \\
\hline Juglans regia L. & 35 & 40 & 15 & 2.00 \\
\hline Curcuma longa L. & 35 & 28 & 25 & 1.96 \\
\hline Zingiber officinale Rosc. & 30 & 45 & 10 & 1.89 \\
\hline Rubia membranacea Diels. & 18 & 38 & 25 & 1.80 \\
\hline Castanea mollissima BI. & 23 & 38 & 18 & 1.76 \\
\hline Perilla frutescens (L.) Britt. & 20 & 22 & 25 & 1.49 \\
\hline Impatiens arguta Hook. & 38 & & 28 & 1.47 \\
\hline Curcuma aromatica Salisb. & 18 & 11 & 35 & 1.42 \\
\hline Morus alba Linnaeus & 18 & 20 & 25 & 1.40 \\
\hline Terminalia chebula Retz. & 13 & 10 & 35 & 1.29 \\
\hline Phytolacca acinosa Roxb & 30 & & 8 & 0.84 \\
\hline Elaeocarpus decipiens Hemsl. & 13 & & 18 & 0.69 \\
\hline Eurya acuminata DC. & 20 & & & 0.44 \\
\hline
\end{tabular}

Table $3 \mathrm{~K} / \mathrm{S}$ values and colorimetric data of madder dyed fabrics with and without mordanting. 


\begin{tabular}{|c|c|c|c|c|c|c|c|c|}
\hline Fabrics & Mordants & $\begin{array}{l}\text { Mordanting } \\
\text { methods }\end{array}$ & $\left(L^{\star}\right)$ & $\left(a^{\star}\right)$ & $\left(b^{*}\right)$ & $\left(\Delta \mathbf{E}^{\star}\right)$ & $\mathrm{K} / \mathrm{S}$ & Samples \\
\hline \multirow{13}{*}{ 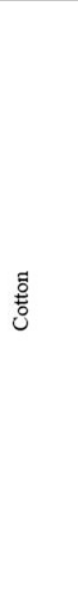 } & Without mordant & -(ID) & 55.93 & 20.87 & 4.43 & 31.19 & 9.23 & \\
\hline & With C. speciosa & Pre-mord. & 63.47 & 13.27 & 11.40 & 20.56 & 10.57 & \\
\hline & & Simult. mord. & 63.78 & 13.48 & 12.73 & 20.72 & 10.62 & \\
\hline & & Post-mord. & 63.53 & 14.05 & 8.96 & 20.78 & 11.52 & \\
\hline & With Gum rosin & Pre-mord. & 57.99 & 19.59 & 7.80 & 28.60 & 9.42 & \\
\hline & & Simult. mord. & 59.64 & 19.93 & 4.19 & 27.93 & 10.93 & \\
\hline & & Post-mord. & 60.95 & 19.23 & 2.99 & 26.81 & 11.96 & \\
\hline & With Alum & Pre-mord. & 55.03 & 23.34 & 9.10 & 33.34 & 8.62 & \\
\hline & & Simult. mord. & 57.71 & 20.20 & 13.24 & 29.66 & 8.62 & \\
\hline & & Post-mord. (ID) & 55.78 & 23.68 & 3.30 & 33.56 & 9.65 & \\
\hline & With Stannous & Pre-mord. & 52.75 & 23.27 & 8.39 & 34.94 & 7.16 & \\
\hline & chloride & Simult. mord. & 51.47 & 20.50 & 13.84 & 34.66 & 5.37 & \\
\hline & & Post-mord. (ID) & 54.03 & 24.48 & 5.37 & 34.95 & 8.33 & \\
\hline \multirow{13}{*}{ 善 } & Without mordant & -(ID) & 53.17 & 24.03 & -1.57 & 39.12 & 8.65 & \\
\hline & With C. speciosa & Pre-mord. & 71.22 & 5.49 & 13.64 & 22.60 & 12.29 & \\
\hline & & Simult. mord. & 69.61 & 8.67 & 12.81 & 24.16 & 10.99 & \\
\hline & & Post-mord. & 71.55 & 7.08 & 12.46 & 22.21 & 11.24 & \\
\hline & With Gum rosin & Pre-mord. & 56.02 & 20.55 & -0.03 & 35.21 & 9.06 & \\
\hline & & Simult. mord. & 60.42 & 17.68 & -2.55 & 29.82 & 11.30 & \\
\hline & & Post-mord. & 62.02 & 16.68 & -4.34 & 27.93 & 12.53 & \\
\hline & With Alum & Pre-mord. & 51.37 & 23.13 & 2.82 & 40.75 & 7.15 & \\
\hline & & Simult. mord. & 55.28 & 19.30 & -3.43 & 34.65 & 10.12 & \\
\hline & & Post-mord. (ID) & 64.49 & 16.04 & 9.92 & 29.52 & 10.33 & \\
\hline & With Stannous & Pre-mord. & 51.49 & 23.52 & 4.01 & 41.15 & 7.04 & \\
\hline & & Simult. mord. & 52.37 & 19.90 & 6.38 & 38.80 & 6.43 & \\
\hline & & Post-mord. (ID) & 52.80 & 23.53 & 1.75 & 39.80 & 7.89 & \\
\hline
\end{tabular}

Notes: ID=Indigenous madder dyeing.

Table $4 \mathrm{~K} / \mathrm{S}$ values and colorimetric data of recycled madder dyed fabrics with and without mordanting. 


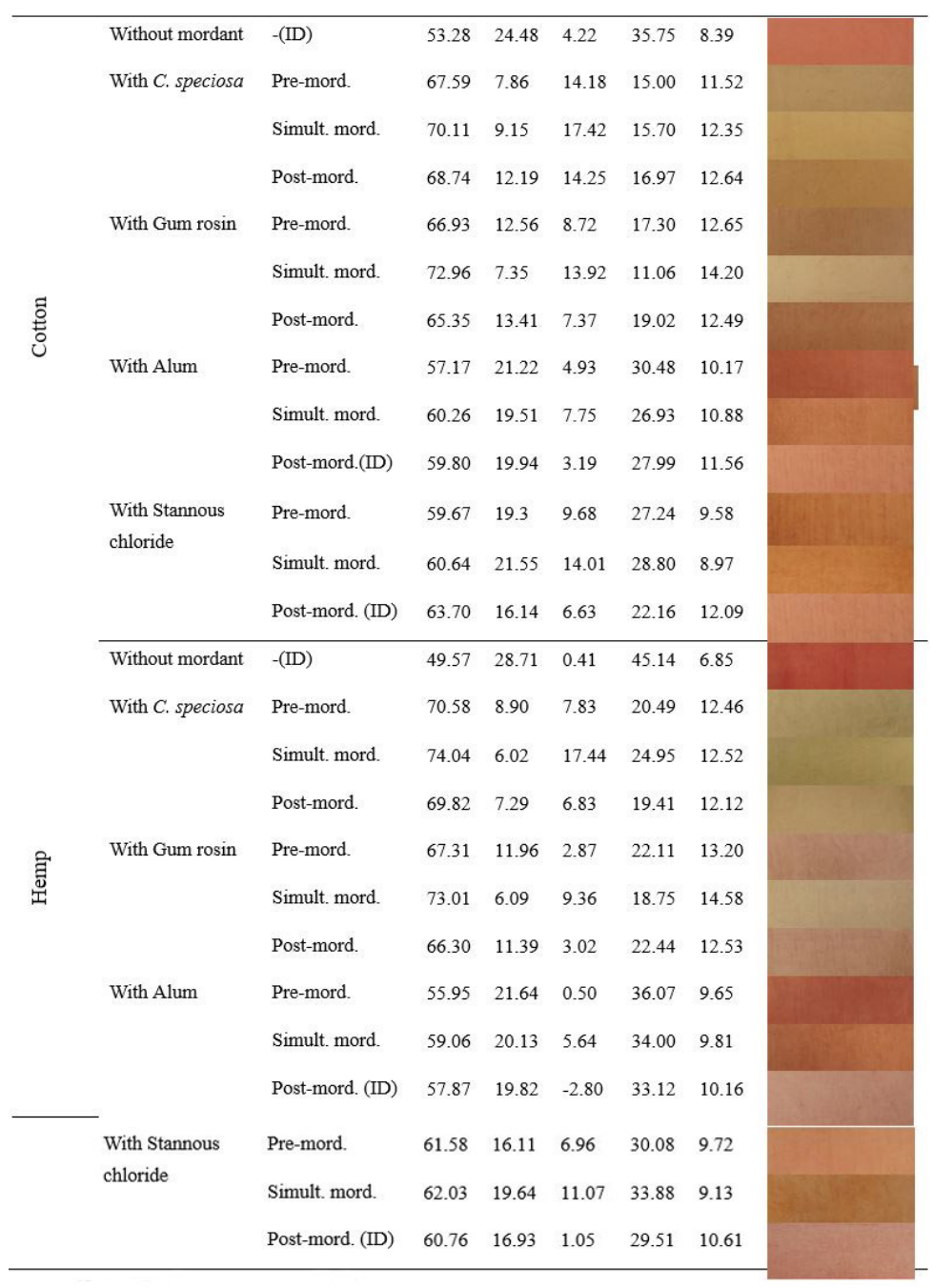

Notes: ID=Indigenous madder dyeing.

\section{Table 5 Colorfastness of the madder dyed two fabrics.}




\begin{tabular}{|c|c|c|c|c|c|c|c|c|c|c|c|c|c|c|c|c|c|}
\hline \multirow[t]{4}{*}{ Mordants } & \multirow{4}{*}{$\begin{array}{l}\text { Mordanting } \\
\text { methods }\end{array}$} & \multicolumn{4}{|c|}{ Washing fastness } & \multicolumn{4}{|c|}{ Rubbing fastness } & \multicolumn{8}{|c|}{ Perspiration fastness } \\
\hline & & & & & & & & & & Acic & & & & Alka & & & \\
\hline & & \multicolumn{2}{|l|}{$\mathrm{CC}$} & \multicolumn{2}{|l|}{$\mathrm{CS}$} & \multicolumn{2}{|l|}{ Dry } & \multicolumn{2}{|l|}{ Wet } & \multicolumn{2}{|l|}{$\mathrm{CC}$} & \multicolumn{2}{|l|}{ CS } & \multicolumn{2}{|l|}{$\mathrm{CC}$} & \multicolumn{2}{|l|}{ CS } \\
\hline & & C & $\mathrm{H}$ & $\mathrm{C}$ & $\mathrm{H}$ & $\mathrm{C}$ & $\mathrm{H}$ & C & $\mathrm{H}$ & C & $\mathrm{H}$ & $\mathrm{C}$ & $\mathrm{H}$ & $\mathrm{C}$ & $\mathrm{H}$ & $\mathrm{C}$ & $\mathrm{H}$ \\
\hline Without mordant & - (ID) & 1 & 1 & 5 & $4-5$ & 5 & $3-4$ & $4-5$ & $3-4$ & 3 & $3-4$ & 4 & $3-4$ & $3-4$ & 3 & 4 & 4 \\
\hline \multirow[t]{3}{*}{ With Gum rosin } & Pre-mord. & $1-2$ & $1-2$ & 4 & $4-5$ & 5 & 5 & 5 & $4-5$ & 3 & 3 & 4 & $4-5$ & $3-4$ & $2-3$ & 4 & $4-5$ \\
\hline & Simult. mord. & $2-3$ & 2 & 4 & 5 & 5 & 5 & 5 & $4-5$ & 3 & 3 & 4 & $4-5$ & 3 & 3 & $4-5$ & 5 \\
\hline & Post-mord. & 3 & $2-3$ & 4 & 5 & 5 & 5 & 5 & 5 & 4 & 3 & $4-5$ & $4-5$ & $3-4$ & $3-4$ & $4-5$ & $4-5$ \\
\hline \multirow[t]{3}{*}{ With C. speciosa } & Pre-mord. & 2 & $2-3$ & 4 & $4-5$ & 5 & 5 & 5 & $4-5$ & $2-3$ & 3 & $4-5$ & $4-5$ & $2-3$ & 4 & $4-5$ & 4 \\
\hline & Simult. mord. & $1-2$ & 2 & 4 & 5 & 5 & 5 & $4-5$ & $4-5$ & 3 & 3 & $4-5$ & $4-5$ & $2-3$ & 2 & 4 & $4-5$ \\
\hline & Post-mord. & $2-3$ & $1-2$ & 4 & $4-5$ & 5 & 5 & 5 & 5 & $3-4$ & 3 & $4-5$ & 5 & 3 & $2-3$ & 4 & 4 \\
\hline \multirow{3}{*}{$\begin{array}{l}\text { With Stannous } \\
\text { chloride }\end{array}$} & Pre-mord. & $1-2$ & $1-2$ & 4 & $4-5$ & 5 & 5 & 5 & $4-5$ & $4-5$ & $3-4$ & $4-5$ & $4-5$ & $2-3$ & $2-3$ & 4 & 4 \\
\hline & Simult. mord. & 1 & $1-2$ & 4 & 5 & $4-5$ & $4-5$ & 5 & $4-5$ & 2 & $2-3$ & $3-4$ & $4-5$ & 4 & $2-3$ & $3-4$ & 4 \\
\hline & Post-mord. (ID) & $1-2$ & $1-2$ & $4-5$ & $4-5$ & $4-5$ & 5 & 5 & $4-5$ & $3-4$ & $3-4$ & $4-5$ & $4-5$ & 3 & $3-4$ & 4 & $4-5$ \\
\hline \multirow[t]{3}{*}{ With Alum } & Pre-mord. & $1-2$ & $1-2$ & 4 & 5 & 5 & 5 & 5 & $4-5$ & 3 & $2-3$ & 4 & $4-5$ & 3 & 3 & $4-5$ & $4-5$ \\
\hline & Simult. mord. & $1-2$ & $1-2$ & 4 & $4-5$ & 5 & 5 & $4-5$ & $4-5$ & 4 & $2-3$ & $4-5$ & $4-5$ & 3 & 4 & 4 & $4-5$ \\
\hline & Post-mord. (ID) & 2 & 2 & 4 & 5 & 5 & 5 & 5 & $4-5$ & $4-5$ & 4 & $4-5$ & $4-5$ & $3-4$ & 4 & 4 & 4 \\
\hline
\end{tabular}

Notes: $\mathrm{CC}=$ Color change, $\mathrm{CS}=$ Color staining $\mathrm{C}=$ Cotton, $\mathrm{H}=$ Hemp, ID=Indigenous madder dyeing.

Table 6 Colorfastness of the recycled madder dyed two fabrics.

\begin{tabular}{|c|c|c|c|c|c|c|c|c|c|c|c|c|c|c|c|c|c|}
\hline \multirow[t]{4}{*}{ Mordants } & \multirow{4}{*}{$\begin{array}{l}\text { Mordanting } \\
\text { methods }\end{array}$} & \multirow{2}{*}{\multicolumn{4}{|c|}{$\begin{array}{l}\text { Washing fastness } \\
\text { fastness }\end{array}$}} & \multirow{2}{*}{\multicolumn{4}{|c|}{ Rubbing fastness }} & \multicolumn{8}{|c|}{ Perspiration fastness } \\
\hline & & & & & & & & & & \multicolumn{4}{|c|}{ Acidic } & \multicolumn{4}{|c|}{ Alkaline } \\
\hline & & \multicolumn{2}{|l|}{$\mathrm{CC}$} & \multicolumn{2}{|l|}{ CS } & \multicolumn{2}{|c|}{ Dry } & \multicolumn{2}{|l|}{ Wet } & \multicolumn{2}{|l|}{$\mathrm{CC}$} & \multicolumn{2}{|l|}{ CS } & \multicolumn{2}{|l|}{$\mathrm{CC}$} & \multicolumn{2}{|l|}{ CS } \\
\hline & & $\mathrm{C}$ & $\mathrm{H}$ & C & $\mathrm{H}$ & C & $\mathrm{H}$ & C & $\mathrm{H}$ & C & $\mathrm{H}$ & C & $\mathrm{H}$ & C & $\mathrm{H}$ & C & $\mathrm{H}$ \\
\hline Without mordant & - (ID) & $1-2$ & $1-2$ & 4 & $4-5$ & $4-5$ & $4-5$ & 4 & $3-4$ & 3 & $3-4$ & $4-5$ & 4 & 3 & 4 & $4-5$ & $4-5$ \\
\hline \multirow[t]{3}{*}{ With Gum rosin } & Pre-mord. & $1-2$ & 2 & 4 & $4-5$ & 5 & 5 & 5 & $4-5$ & $2-3$ & 3 & $4-5$ & 5 & $2-3$ & 3 & $4-5$ & 4 \\
\hline & Simult. mord. & $2-3$ & $2-3$ & $4-5$ & $4-5$ & 5 & $4-5$ & 5 & 5 & 3 & 4 & $4-5$ & $4-5$ & 3 & 3 & $4-5$ & $4-5$ \\
\hline & Post-mord. & 3 & $2-3$ & 4 & 5 & 5 & 5 & 5 & 5 & 3 & 4 & $4-5$ & $4-5$ & 4 & $3-4$ & $4-5$ & $4-5$ \\
\hline \multirow[t]{3}{*}{ With C. speciosa } & Pre-mord. & $1-2$ & $2-3$ & 4 & $4-5$ & 5 & 5 & 5 & 5 & $2-3$ & 3 & $4-5$ & $4-5$ & 3 & 4 & 4 & 5 \\
\hline & Simult. mord. & 2 & $1-2$ & 4 & $4-5$ & 5 & 5 & $4-5$ & 5 & 2 & $1-2$ & $4-5$ & $4-5$ & 2 & 2 & 4 & $4-5$ \\
\hline & Post-mord. & 3 & 3 & 4 & $4-5$ & 5 & 5 & 5 & 5 & 3 & 4 & $4-5$ & $4-5$ & 4 & $3-4$ & $4-5$ & $4-5$ \\
\hline \multirow{3}{*}{$\begin{array}{l}\text { With Stannous } \\
\text { chloride }\end{array}$} & Pre-mord. & $1-2$ & $1-2$ & 4 & $4-5$ & 5 & 5 & 5 & 5 & 4 & 4 & $4-5$ & $4-5$ & $3-4$ & $2-3$ & 4 & 5 \\
\hline & Simult. mord. & $1-2$ & $1-2$ & $4-5$ & 5 & $4-5$ & $4-5$ & $4-5$ & 5 & 3 & 3 & $4-5$ & $4-5$ & $3-4$ & 3 & $4-5$ & $4-5$ \\
\hline & Post-mord. (ID) & $2-3$ & 3 & 4 & 5 & 5 & 5 & 5 & 5 & 4 & 3 & $4-5$ & $4-5$ & 4 & 3 & $4-5$ & $4-5$ \\
\hline \multirow[t]{3}{*}{ With Alum } & Pre-mord. & $1-2$ & $1-2$ & $4-5$ & $4-5$ & 5 & $4-5$ & $4-5$ & 5 & $4-5$ & 3 & 5 & 5 & 3 & $3-4$ & $4-5$ & $4-5$ \\
\hline & Simult. mord. & $1-2$ & $1-2$ & 4 & 5 & 5 & $4-5$ & $4-5$ & $4-5$ & $3-4$ & 2 & $4-5$ & $4-5$ & 3 & $2-3$ & $4-5$ & $4-5$ \\
\hline & Post-mord. (ID) & $1-2$ & 2 & 4 & $4-5$ & 5 & 5 & $4-5$ & 5 & 4 & 4 & $4-5$ & $4-5$ & $4-5$ & $3-4$ & $4-5$ & $4-5$ \\
\hline
\end{tabular}

Notes: $\mathrm{CC}=$ Color change, $\mathrm{CS}=$ Color staining, $\mathrm{C}=$ Cotton, $\mathrm{H}=$ Hemp, ID=Indigenous madder dyeing.

Table 7 Comparative cost of synthetic and plant dyeing for $1 \mathrm{~kg}$ fabrics. 


\begin{tabular}{|llll|}
\hline Item & \multicolumn{2}{l|}{ Dye type } & \\
\cline { 2 - 4 } & Madder dyeing & $\begin{array}{l}\text { Recycled madder } \\
\text { dyeing }\end{array}$ & Synthetic dyeing \\
\hline Raw materials & $29.8 ¥$ & - & $21.3 ¥$ \\
\hline Extraction and dyeing process & $100.2 ¥$ & $120.0 ¥$ & $68.2 ¥$ \\
\hline Additives & $5.0 ¥$ & $5.0 ¥$ & $8.5 ¥$ \\
\hline Wastewater treatment $\left(\mathrm{m}^{3}\right)$ & - & - & $2.2 ¥$ \\
\hline Total & $135 ¥$ & $125 ¥$ & $100.2 ¥$ \\
\hline
\end{tabular}

\section{Figures}

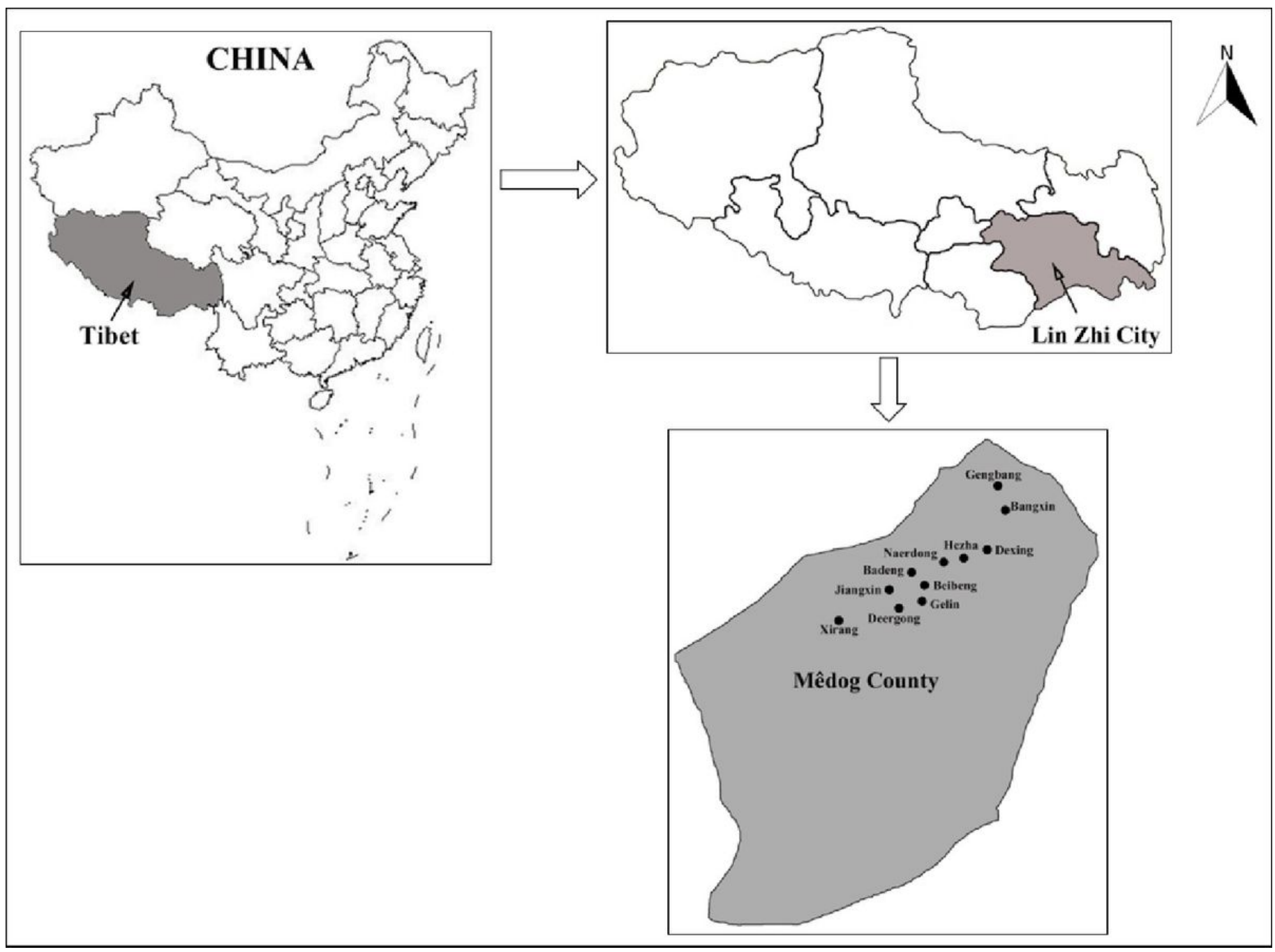

Figure 1

The location of 11 study villages in Mêdog County, Lin Zhi City, Tibet, China. Note: The designations employed and the presentation of the material on this map do not imply the expression of any opinion whatsoever on the part of Research Square concerning the legal status of any country, territory, city or area or of its authorities, or concerning the delimitation of its frontiers or boundaries. This map has been provided by the authors. 


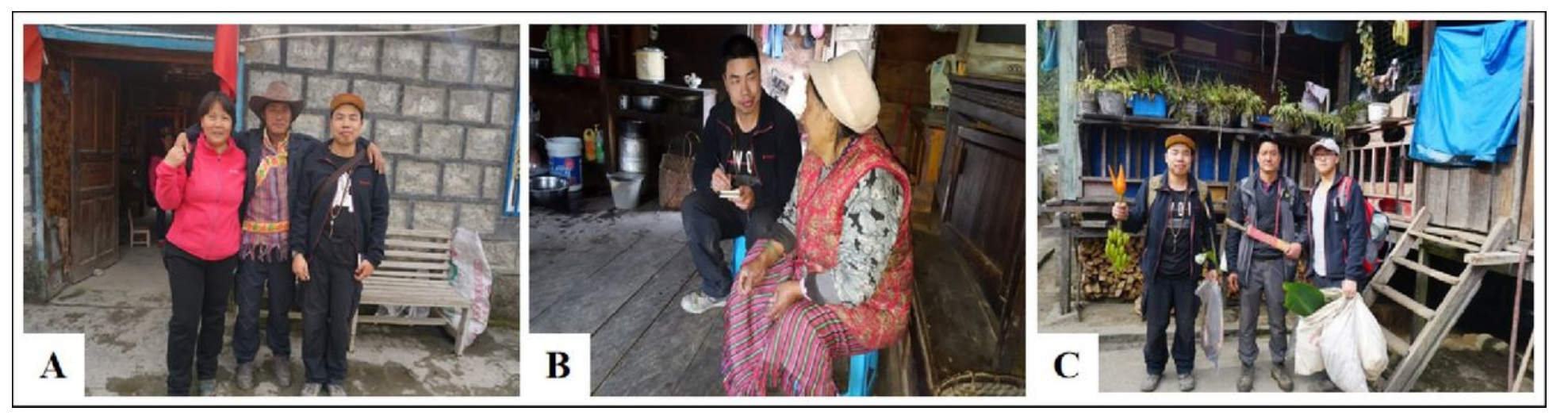

Figure 2

The research team conducted an ethnobotanical survey in De' ergong Village, Beibeng Township of Mêdog County, Tibet, China. a The research team was in De' ergong Village with a Monpa informant. b Semi-structured interviews were conducted with local Monpa grandmothers. c According to the field research to collect local dye plant samples.
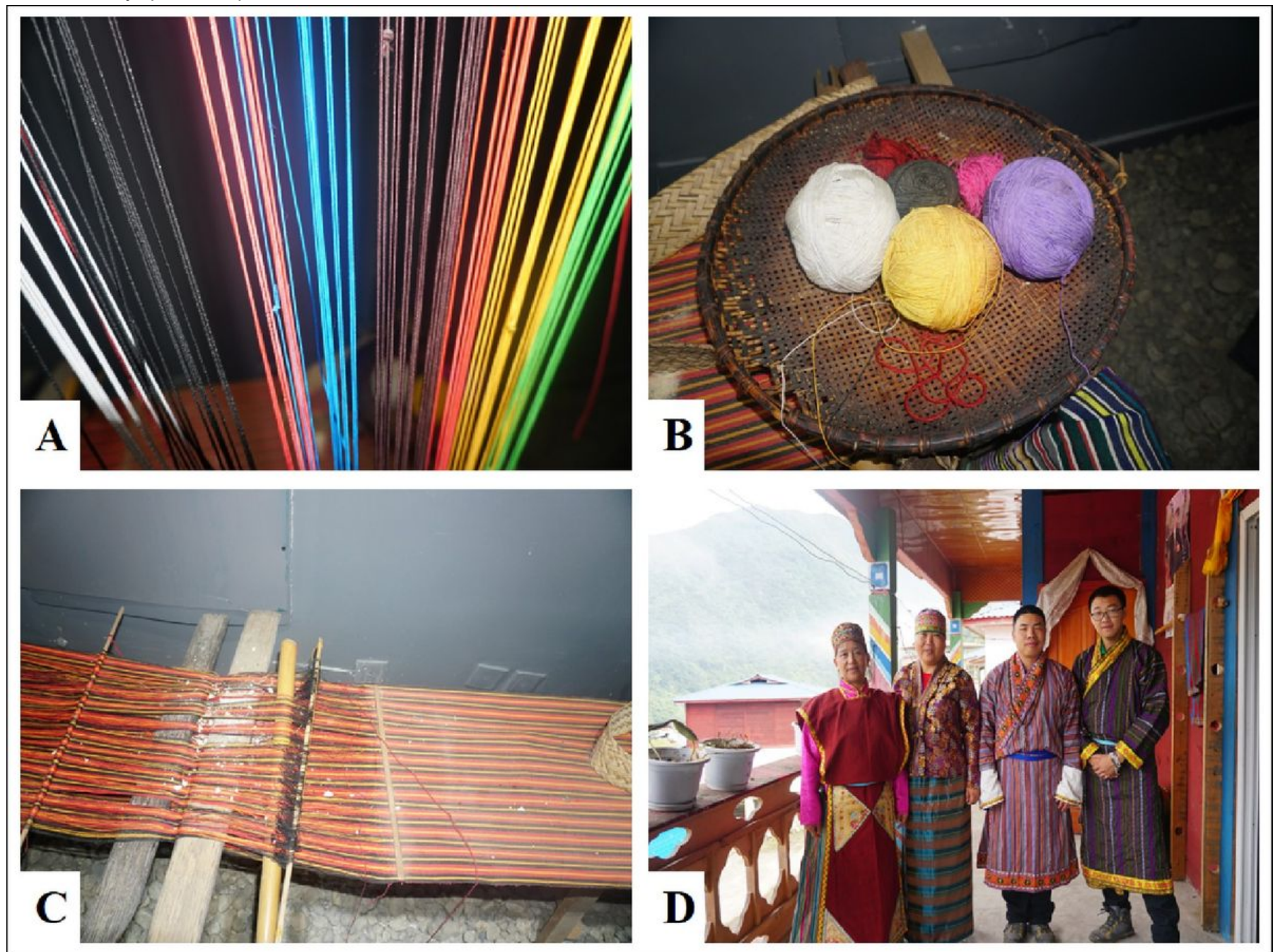

Figure 3

The national clothes of the Menba people dyed with madder. a The lines of cotton and hemp dyed with plant dyes, and the red line was dyed by madder. $b$ The plant dyed lines were twined into balls and installed on traditional textile tools. $c$ The dye lines with red as the main line were woven into clothes. $d$ Monpa clothes were made by traditional craft. 


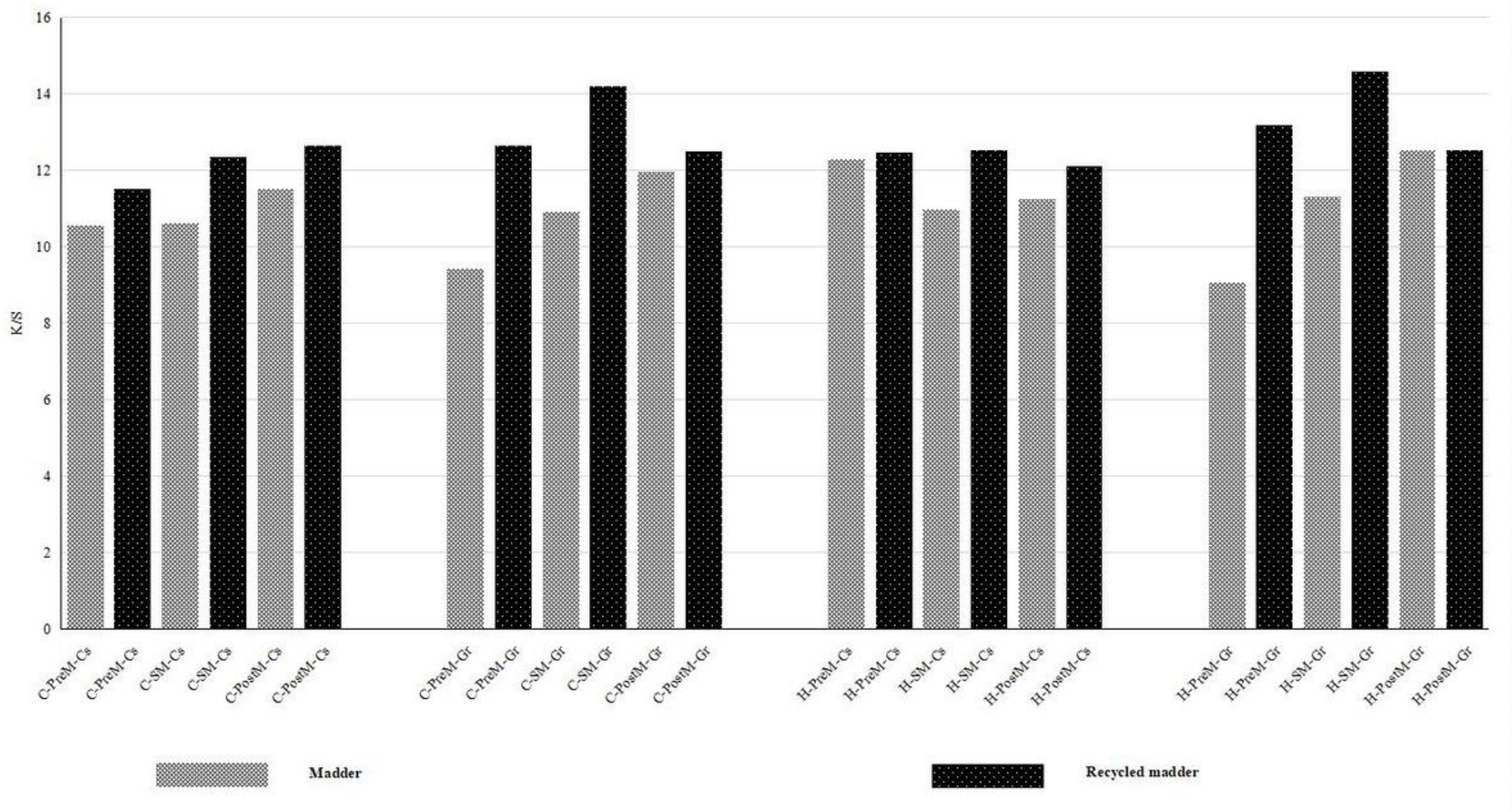

\section{Figure 4}

Comparison of color strength between madder and recycled madder with biomordants. (Mordants: $\mathrm{Cs}=\mathrm{C}$. speciosa, Gr=Gum rosin; Fabrics: $\mathrm{C}=\mathrm{Cotton}, \mathrm{H}=$ Hemp).
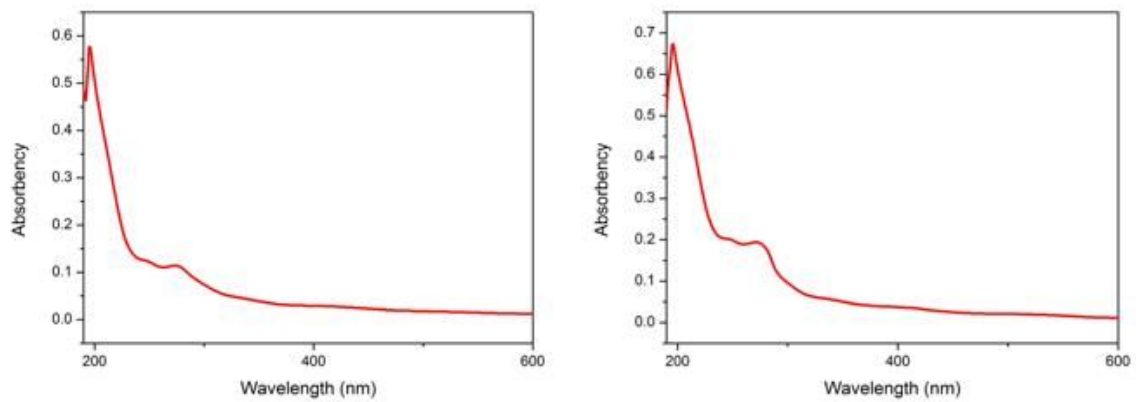

\section{Figure 5}

UV-vis spectrum of madder aqueous extraction (left) and madder ethyl alcohol extraction (right).
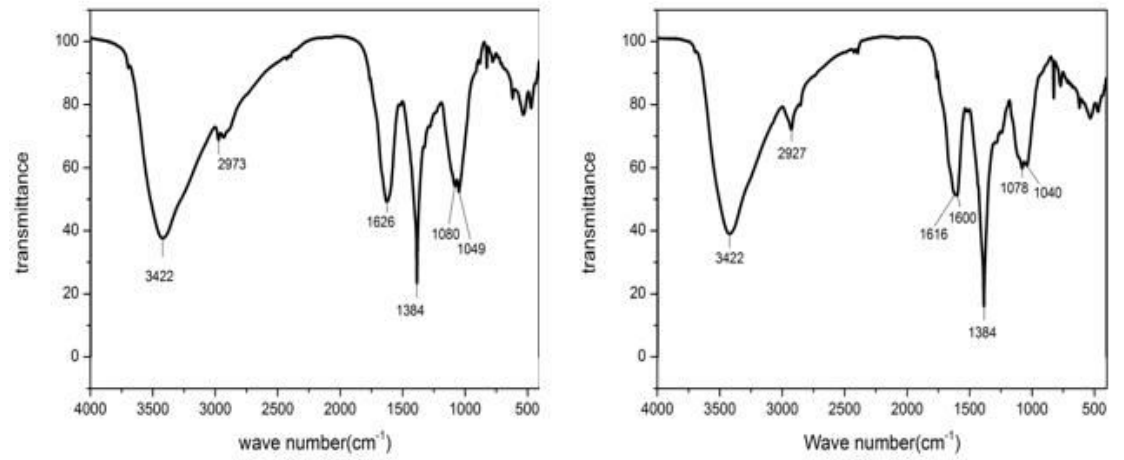

Figure 6

FTIR spectrum of madder aqueous extraction (left) and madder ethyl alcohol extraction (right). 


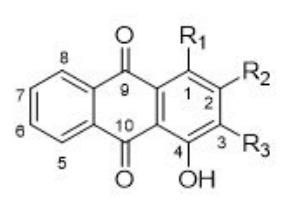

$$
\begin{aligned}
& \text { 1. } \mathrm{R}_{1}=\mathrm{R}_{3}=\mathrm{OH}, \mathrm{R}_{2}=\mathrm{H}_{1} \\
& \text { 2. } \mathrm{R}_{1}=\mathrm{R}_{3}=\mathrm{H}, \mathrm{R}_{2}=\mathrm{OH}_{1} \\
& \text { 3. } \mathrm{R}_{1}=\mathrm{R}_{2}=\mathrm{H}, \mathrm{R}_{3}=\mathrm{CH}_{3} \\
& \text { 4. } \mathrm{R}_{1}=\mathrm{H}, \mathrm{R}_{2}=\mathrm{OH}, \mathrm{R}_{3}=\mathrm{CH}_{3} ; \\
& \text { 5. } \mathrm{R}_{1}=\mathrm{H}, \mathrm{R}_{2}=\mathrm{OH}, \mathrm{R}_{3}=\mathrm{CHO} \\
& \text { 6. } \mathrm{R}_{1}=\mathrm{H}, \mathrm{R}_{2}=\mathrm{OH}, \mathrm{R}_{3}=\mathrm{CH}_{2} \mathrm{OH} ; \\
& \text { 7. } \mathrm{R}_{1}=\mathrm{H}, \mathrm{R}_{2}=\mathrm{OH}, \mathrm{R}_{3}=\mathrm{COOCH}_{3} \text {. }
\end{aligned}
$$

Figure 7

Chemical structures of anthraquinone derivatives found in the roots of R. wallichiana.

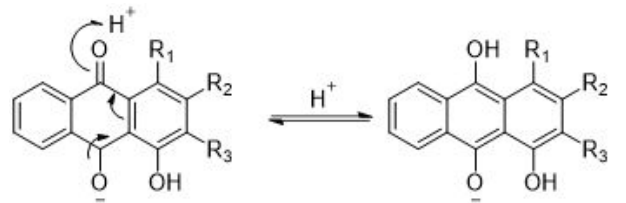

Figure 8

The proposed possible mechanism between C. speciosa, cotton/hemp fabrics and the pigment of R. wallichiana.

\section{Supplementary Files}

This is a list of supplementary files associated with this preprint. Click to download.

- Graphicalabstract.pdf 